\title{
The effects of short periods of fasting on the absorption of heavy metals
}

\author{
BY J. QUARTERMAN AND ELAINE MORRISON \\ Rowett Research Institute, Greenburn Road, Bucksburn, Aberdeen AB2 9SB
}

(Received 18 March 1981 - Accepted 12 May 1981)

1. Rats were deprived of food for periods of from 0 to $40 \mathrm{~h}$ and then given ${ }^{203} \mathrm{~Pb},{ }^{203} \mathrm{Hg},{ }^{59} \mathrm{Fe},{ }^{64} \mathrm{Cu},{ }^{65} \mathrm{Zn}$ or ${ }^{45} \mathrm{Ca}$ by stomach tube. The absorption and retention of these metals in tissues was measured $1 \mathrm{~h}$ and $2 \mathrm{~d}$ after dosing.

2. After 16-24 h of food deprivation between two and ten times more metal was retained than after 0-12 h.

3. The effects of length of fast on metal uptake by the intestinal mucosa were greatest in the duodenum.

4. Lactate production by duodenal mucosa was halved after $12 \mathrm{~h}$ of food deprivation but galactose absorption was little changed after a $40 \mathrm{~h}$ iast.

Most studies of the effects of fasting on intestinal absorption of organic and inorganic substances have involved total starvation for periods of approximately $3 \mathrm{~d}$ (for example, Steiner \& Gray, 1969; Newry et al. 1970; Beck \& Dinda, 1973; Lichtenberger et al. 1976). Such starvation periods produce considerable changes in the size and morphology of the intestinal mucosa. Fasting for $24 \mathrm{~h}$ or less also produces smaller but measurable effects on the weight and total DNA of the mucosa and on the absorption of sugars, fats and some drugs (Mead et al. 1951; McManus \& Isselbacher, 1970; Orr \& Benet, 1975).

An increase of heavy metal absorption due to short fasts has been reported by many workers (for example, Taylor et al. 1962; Ekenved \& Arvidsson, 1976; Gruden \& Buben, 1979) and food restriction over a period of weeks increased the retention of lead (Quarterman et al. 1976), but the process has not been examined in detail. We were particularly interested in the shorter periods of fasting for several reasons. These periods occur in normal circumstances, in animals or humans eating one or two meals daily and even overnight. Subjects exposed to toxic or essential metals may modify their retention of these metals according to their meal-eating pattern. Such considerations may be particularly important in experiments in which subjects are prepared (usually by overnight fasting) for observations on metal retention.

\section{MATERIALS AND METHODS}

Metal absorption experiments. Male Hooded Lister (Rowett strain) rats weighing approximately $100 \mathrm{~g}$ were used in all the experiments except one. The food was a semi-purified diet based on that of Williams \& Mills (1970) but containing casein instead of albumin. For 1 week before the experiments the rats were allowed free access to food for two $1 \mathrm{~h}$ periods daily, and then deprived of food for periods of from 0 to $40 \mathrm{~h}$. Five or six rats were used for each fasting period. After the period of fasting they were given approximately $5 \mu \mathrm{Ci}$ $(135 \mathrm{kBq})$ of radioactive metal ion in saline $(9 \mathrm{~g}$ sodium chloride/l) by tube into the stomach. Exactly $1 \mathrm{~h}$ after this dose a sample of blood was taken from the tail and the rats were restored to their normal meal-feeding regimen. This involved immediate feeding except in the instance of those ra.ts which were dosed directly after a meal. At $2 \mathrm{~d}$ after dosing ( $1 \mathrm{~d}$ when ${ }^{64} \mathrm{Cu}$ was used) the rats were killed and samples of blood, liver, kidney and in some instances bone and intestinal mucosa were removed for estimation of radioactivity. The radioactivity due to all the metal isotopes (except ${ }^{45} \mathrm{Ca}$ ) in tissues was measured using a 
Tracerlab (Gammaguard) gamma-counter or in the gut-free carcass using a small whole-body counter. For the determination of ${ }^{45} \mathrm{Ca}$ activity soft tissues and dry, fat-free femurs were ashed at $400^{\circ}$, the ash dissolved in $2 \mathrm{M}$-nitric acid and the solution neutralized with $2 \mathrm{M}$-sodium hydroxide. Activity was then measured in this solution by liquid-scintillation counting, using toluene containing 4.0 g PPO and $50 \mathrm{mg}$ POPOP/1-Triton X $100(3: 1, \mathrm{v} / \mathrm{v})$, and a Beckman LS 345 liquid-scintillation counter. ${ }^{59} \mathrm{Fe}(3-20 \mathrm{mCi} / \mathrm{mg}){ }^{203} \mathrm{Hg}(0 \cdot 3-2 \mathrm{mCi} / \mathrm{mg})$, ${ }^{45} \mathrm{Ca}(10-40 \mathrm{mCi} / \mathrm{mg}),{ }^{64} \mathrm{Cu}(5-30 \mathrm{mCi} / \mathrm{mg})$ and ${ }^{65} \mathrm{Zn}(0 \cdot 1-2.5 \mathrm{mCi} / \mathrm{mg})$ were supplied by The Radiochemical Centre Ltd, Amersham, Bucks. ${ }^{203} \mathrm{~Pb}$ (carrier-free) came from the Medical Research Council Cyclotron Unit, Hammersmith Hospital, London.

In one experiment carrier (non-radioactive) $\mathrm{Fe}$ was added to isotope in the form of a freshly-prepared solution of ferrous sulphate. In this experiment the rats were killed $1 \mathrm{~h}$ after dosing and $\mathrm{Fe}, \mathrm{Zn}$ and $\mathrm{Cu}$ estimated in the duodenal mucosa by atomic absorption spectrophotometry after wet ashing (Quarterman et al. 1976). Fe-deficient rats were prepared by feeding 4-week-old rats with the semi-purified diet to which no Fe salts had been added. The diet then contained approximately $2 \mu \mathrm{g} \mathrm{Fe} / \mathrm{g}$. After $12 \mathrm{~d}$ on this diet their blood haemoglobin concentration was $97 \pm 3 \mathrm{~g} / \mathrm{l}$ whereas that of rats given the control, Fe-supplemented diet was $128 \pm 2 \mathrm{~g} / 1$.

In a final experiment six groups of six rats weighing approximately $300 \mathrm{~g}$ were starved for periods of time up to $3 \mathrm{~d}$ and the activity of ${ }^{203} \mathrm{~Pb}$ in tissues and carcass measured $1 \mathrm{~h}$ after an oral dose of the isotope.

Galactose absorption. Rats which had been deprived of food for 0,12 or $24 \mathrm{~h}$ were anaesthetized with sodium pentabarbitone and a $70 \mathrm{~mm}$ loop of intestine tied off, the proximal ligature being approximately $10 \mathrm{~mm}$ from the pylorus and distal to the entrance of the bile duct. Galactose $(10 \mathrm{~mm} ; 0.5 \mathrm{ml})$ in water was injected into the loop before it was tied off and after $3 \mathrm{~min}$ the entire loop was removed from the rat, opened and washed out. Galactose remaining in the loop was estimated by a method using galactose dehydrogenase (Boehringer Corporation (London) Ltd).

Lactate production. Everted intestinal rings were prepared from the duodenums of rats deprived of food for 0,12 or $24 \mathrm{~h}$. Rings $\left(50-100 \mathrm{mg}\right.$ ) were incubated at $37^{\circ}$ in $2 \mathrm{ml}$ Krebs-Ringer bicarbonate buffer containing $10 \mathrm{~mm}$-glucose and gassed with oxygen-carbon dioxide $(95: 5, \mathrm{v} / \mathrm{v})$. Lactate production was estimated at intervals up to $1 \mathrm{~h}$ by a method using lactate dehydrogenase (Boehringer Corporation (London) Ltd).

EXPERIMENTS AND RESULTS

In the first experiment (Table 1) the uptake of oral ${ }^{59} \mathrm{Fe}$ was much greater when the rats had been fasted for 16 or $24 \mathrm{~h}$ than when the isotope was given immediately after a meal or after only $6 \mathrm{~h}$ fasting. In blood samples taken $1 \mathrm{~h}$ after ${ }^{59} \mathrm{Fe}$ was given activity was enhanced 5- to 10-fold by fasting. In blood and other tissues including the gut-free carcass, sampled $2 \mathrm{~d}$ after the dose of ${ }^{58} \mathrm{Fe}$, fasting increased isotope retention 2- or 3-fold. The smallest increase in activity was found in the mucosa (taken from the whole intestine) and after a fast of $40 \mathrm{~h}$ there was no increase in activity above that observed with no fast. In six further experiments using ${ }^{203} \mathrm{~Pb},{ }^{203} \mathrm{Hg},{ }^{64} \mathrm{Cu},{ }^{65} \mathrm{Zn},{ }^{45} \mathrm{Ca}$ and ${ }^{59} \mathrm{Fe}$ similar changes in retention in all tissues were found in response to increasing lengths of fast. The activities in blood $1 \mathrm{~h}$ and in blood and carcass $2 \mathrm{~d}$ after the administration of isotope are shown in Fig. 1. The length of fast after which absorption began to increase was defined more clearly in an experiment with ${ }^{203} \mathrm{~Pb}$ (Table 2). After a $12 \mathrm{~h}$ fast no increase in absorption had occurred but after a $16 \mathrm{~h}$ fast it had increased by between 2 - and 15 -fold. The effects of a $40 \mathrm{~h}$ fast differed from experiment to experiment, the retention of isotope being sometimes greater than, sometimes less than and sometimes the same as the retention after a $16 \mathrm{~h}$ fast (Tables 1 and 2, Fig. 1). 


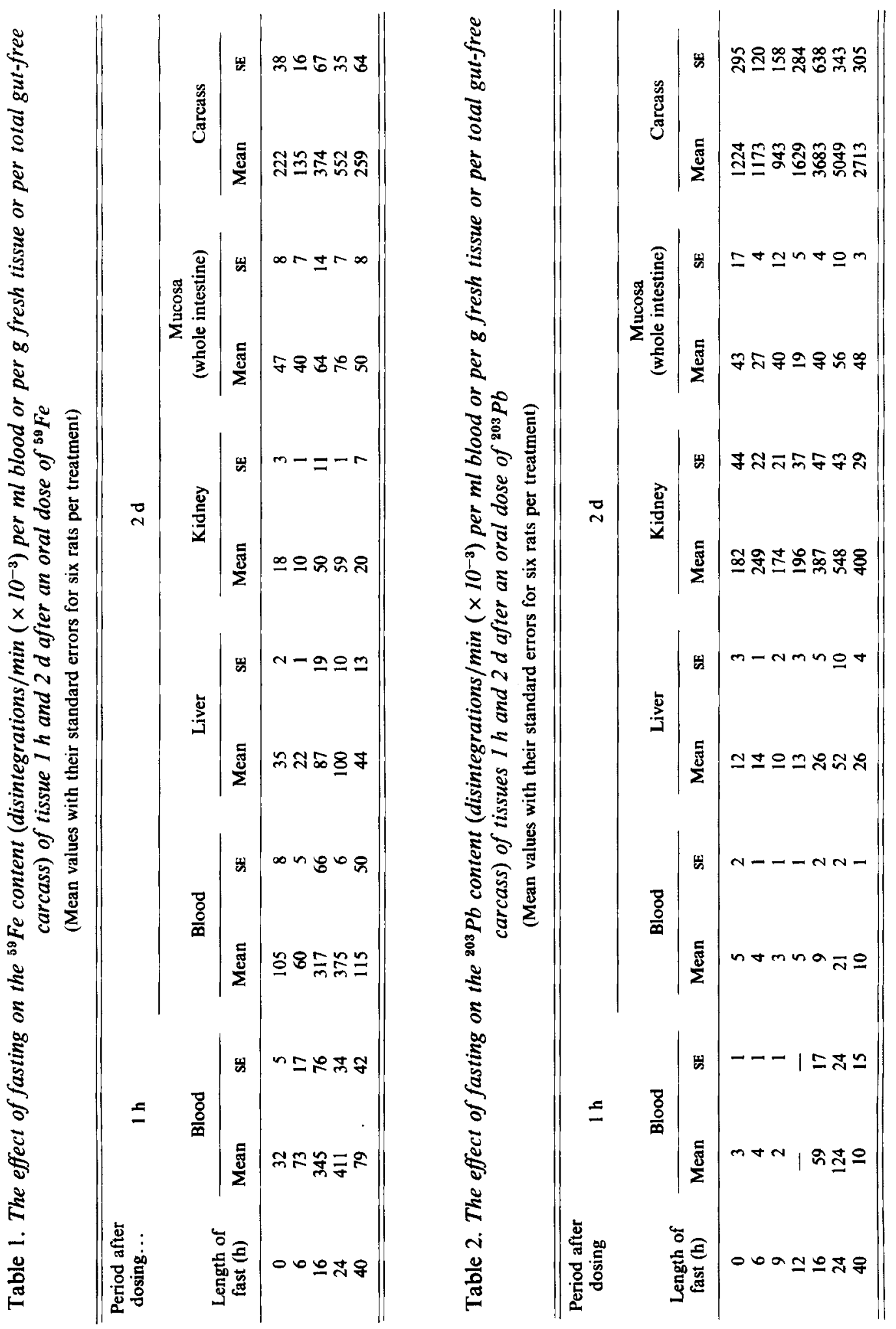



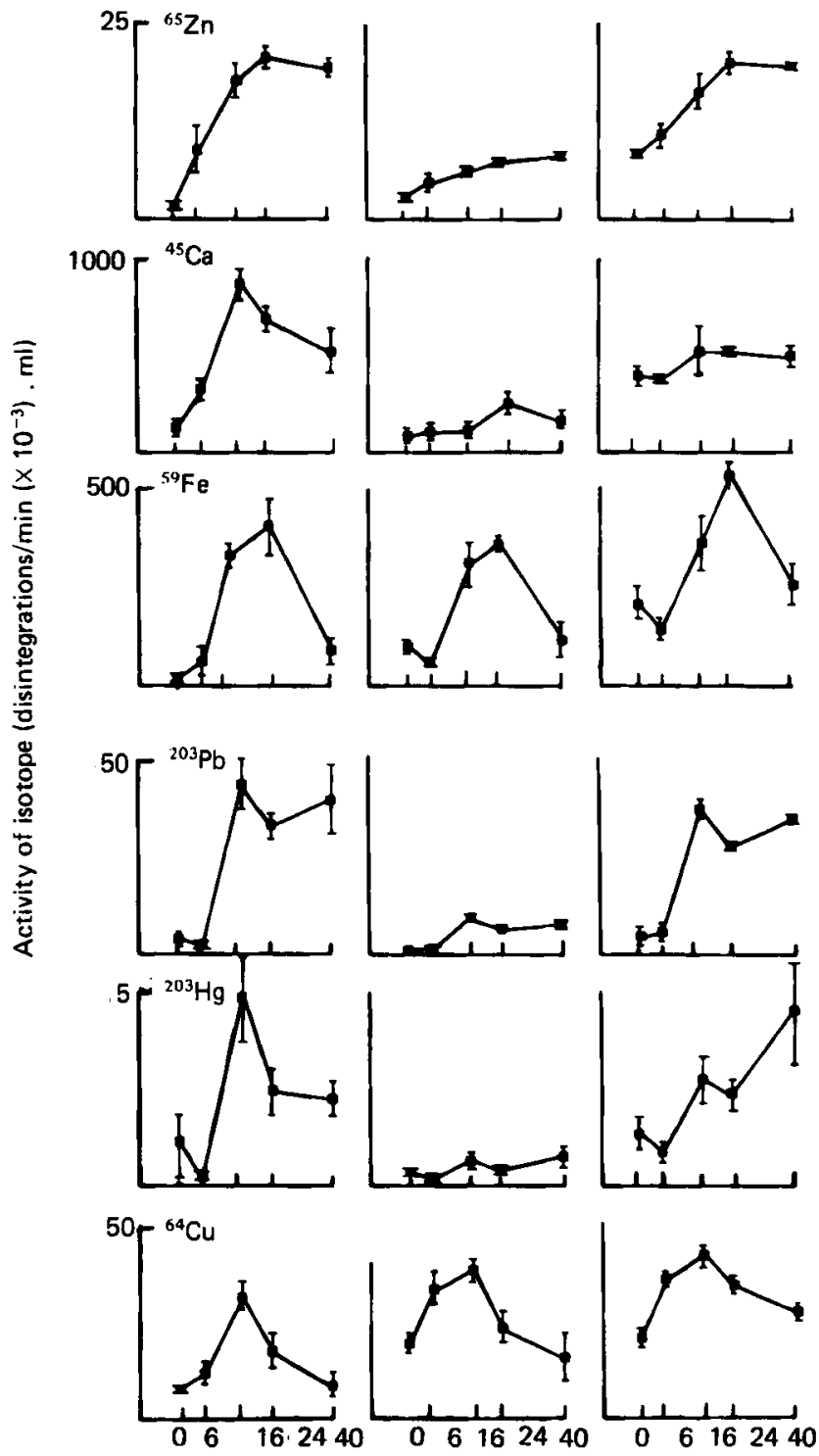

Length of fast $(h)$

Fig. 1. The effect of fasting on the activities (disintegrations/min $\left(\times 10^{-3}\right)$ per $\mathrm{ml}$ ) of ${ }^{209} \mathrm{~Pb},{ }^{203} \mathrm{Hg},{ }^{84} \mathrm{Cu}$, ${ }^{65} \mathrm{Zn}{ }^{45} \mathrm{Ca}$ or ${ }^{59} \mathrm{Fe}$ in blood of rats $1 \mathrm{~h}$ after an oral dose of approximately $5 \mu \mathrm{Ci}$ of isotope and in blood and carcass $2 \mathrm{~d}$ after the dose. Mean values with their standard errors represented by vertical bars.

Fasting caused only small increases in the uptake of metal isotopes by the mucosa averaged over the whole intestine $2 \mathrm{~d}$ after the dose (Tables 1 and 2), but the uptake by different parts of the mucosa after $1 \mathrm{~h}$ was examined in experiments with ${ }^{203} \mathrm{~Pb}$ and ${ }^{59} \mathrm{Fe}$ (Fig. 2). The effect of fasting was clearly greatest on the duodenal mucosa and relatively small on that of the jejunum and ileum. 


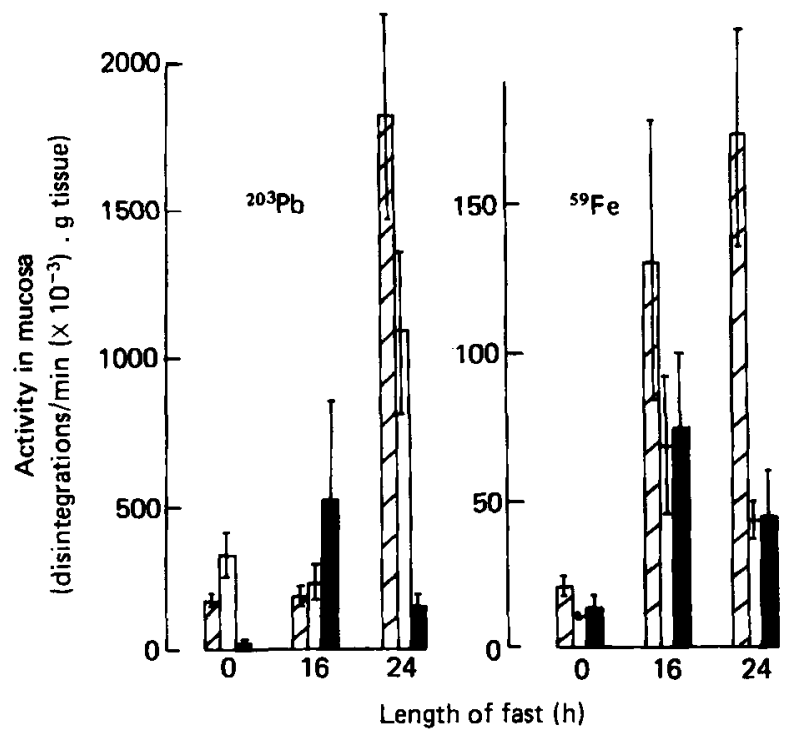

Fig. 2. The content (disintegrations $/ \mathrm{min}\left(\times 10^{-3}\right)$ per $\mathrm{g}$ tissue) of ${ }^{203} \mathrm{~Pb}$ or ${ }^{59} \mathrm{Fe}$ in the mucosa of duodenum $(\square)$, jejunum $(\square)$ and ileum ( $\square$ ) of rats given ${ }^{203} \mathrm{~Pb}$ as lead chloride or ${ }^{68} \mathrm{Fe}$ as ferrous sulphate orally after fasts of 0,16 or $24 \mathrm{~h}$. Mean values with their standard errors represented by vertical bars.

All these experiments were conducted on rats which had been habituated to a meal-feeding regimen, that is, two $1 \mathrm{~h} \mathrm{meals/d}$. In an experiment with ${ }^{203} \mathrm{~Pb}$, rats so trained were compared with rats which had food available continuously. Meal-fed rats tended to absorb more ${ }^{203} \mathrm{~Pb}$ than continuously-fed rats but the effect of feeding pattern was much smaller than the effect of a $16 \mathrm{~h}$ fest, except in the duodenal mucosa (Table 3). The effect of feeding pattern on ${ }^{203} \mathrm{~Pb}$ uptake which was seen after $6 \mathrm{~h}$ and $24 \mathrm{~h}$ fasts was absent after a $16 \mathrm{~h}$ fast.

With an essential trace element such as Fe the effect of fasting on absorption may be modified by the amount of carrier (non-radioactive) element present or by an adaptive increase in absorptive efficiency induced by deficiency. The addition of 0,10 or $50 \mu \mathrm{g}$ stable $\mathrm{Fe}$ to the ${ }^{59} \mathrm{Fe}$ dose did no: eliminate the enhancing effect of starvation upon ${ }^{59} \mathrm{Fe}$ absorption measured $1 \mathrm{~h}$ after dosing,, even though it was apparent that increases in carrier $\mathrm{Fe}$ reduced ${ }^{59} \mathrm{Fe}$ retention by blood and carcass (Table 4). In this experiment the concentrations of total $\mathrm{Fe}, \mathrm{Zn}$ and $\mathrm{Cu}$ were estimated in the duodenal mucosa (Table 5). Fasting did not affect these concentrations. Up:ake of ${ }^{59} \mathrm{Fe}$ by rats given an $\mathrm{Fe}$-deficient diet for $12 \mathrm{~d}$ was greater than that of rats of normal $\mathrm{Fe}$ status but the effect of a $16 \mathrm{~h}$ fast on ${ }^{59} \mathrm{Fe}$ absorption (Table 6) was not eliminated.

In an attempt to relare the observed effects of fasting on metal absorption to other activities of the intestine, galactose absorption and lactate production were measured at 0 , 12 and $24 \mathrm{~h}$ after a meal. Galactose loss from the ligated loops was $0.76 \pm 0.05,0.78 \pm 0.06$ and $1.12 \pm 0.15 \mathrm{mg} / \mathrm{g}$ fresh tissue per min respectively at the three fasting periods while lactate production was $2.00 \pm 0.10,1.05 \pm 0.07$ and $1.47 \pm 0.67 \mathrm{mg} / \mathrm{g}$ fresh weight per $\mathrm{h}$ respectively.

The rate of absorption of oral doses of isotopes may be influenced by the amount of stomach contents at the ime of dosing. The weight of stomach contents was measured in the 'feeding-pattern' experiment. There was no effect of feeding pattern so the values from both feeding groups were pooled. The weights of contents were, after $6 \mathrm{~h}$ fast $0.75 \pm 0.16 \mathrm{~g}$, 


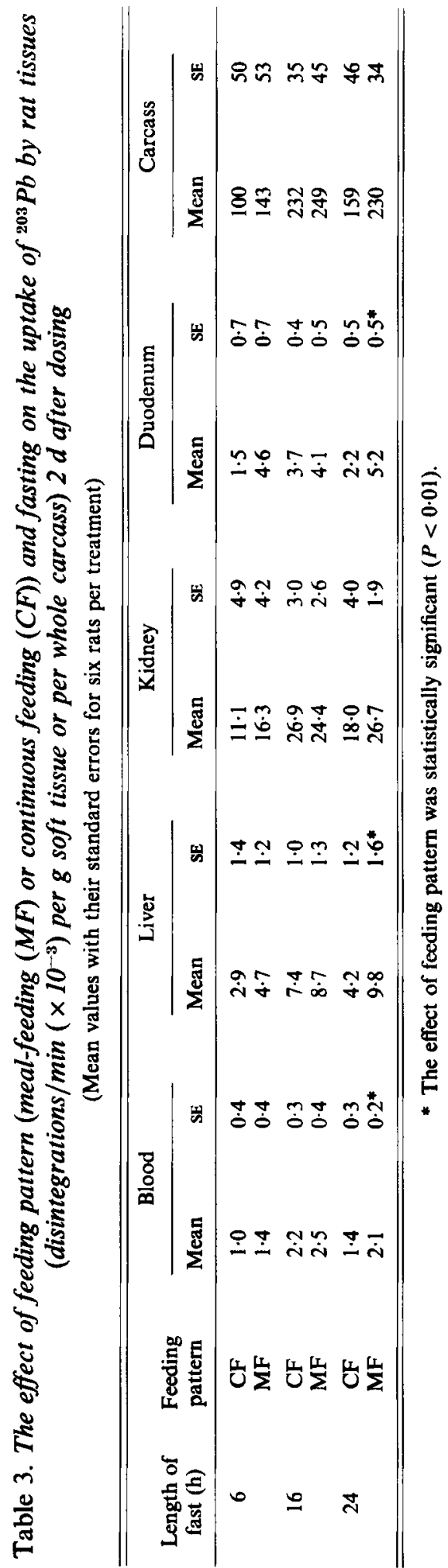


Table 4. The effect of carrier iron and fasting on the uptake of ${ }^{59} \mathrm{Fe}$ by rat tissues (disintegrations/min $\left(\times 10^{-3}\right)$ per $g$ tissue or per whole carcass) 1 h after dosing

(Mean values with their standard errors for seven rats per treatment)

\begin{tabular}{|c|c|c|c|c|c|c|c|}
\hline \multirow{2}{*}{$\begin{array}{l}\text { Length of } \\
\text { fast (h) }\end{array}$} & \multirow{2}{*}{$\begin{array}{l}\text { Carrier } \\
\mathrm{Fe}(\mu \mathrm{g})\end{array}$} & \multicolumn{2}{|c|}{ Blood } & \multicolumn{2}{|c|}{ Duodenal mucosa } & \multicolumn{2}{|c|}{ Carcass } \\
\hline & & Mean & SE & Mean & $\mathbf{S E}$ & Mean & $\mathbf{S E}$ \\
\hline 0 & $\begin{array}{r}0 \\
10 \\
50\end{array}$ & $\begin{array}{l}8 \cdot 1 \\
8 \cdot 0 \\
5 \cdot 9\end{array}$ & $\begin{array}{l}2.3 \\
2.0 \\
0.9\end{array}$ & $\begin{array}{l}51 \\
54 \\
51\end{array}$ & $\begin{array}{l}14 \\
14 \\
12\end{array}$ & $\begin{array}{r}143 \\
58 \\
43\end{array}$ & $\begin{array}{r}95 \\
13 \\
6\end{array}$ \\
\hline 16 & $\begin{array}{r}0 \\
10 \\
50\end{array}$ & $\begin{array}{l}41 \\
30 \\
18\end{array}$ & $\begin{array}{l}9 \\
6 \\
2^{*}\end{array}$ & $\begin{array}{l}308 \\
260 \\
327\end{array}$ & $\begin{array}{r}134 \\
81 \\
69\end{array}$ & $\begin{array}{r}331 \\
283 \\
90\end{array}$ & $\begin{array}{l}92 \\
93 \\
12^{*}\end{array}$ \\
\hline 24 & $\begin{array}{r}0 \\
10 \\
50\end{array}$ & $\begin{array}{l}66 \\
54 \\
29\end{array}$ & $\begin{array}{l}13 \\
8 \\
3^{*}\end{array}$ & $\begin{array}{l}115 \\
252 \\
340\end{array}$ & $\begin{array}{l}47 \\
46 \\
95\end{array}$ & $\begin{array}{l}801 \\
464 \\
334\end{array}$ & $\begin{array}{l}37 \\
50^{*} \\
65^{*}\end{array}$ \\
\hline
\end{tabular}

- The sffect of carrier Fe was statistically significant $(P<0 \cdot 05)$.

Table 5. The effects of jasting on the concentrations ( $\mu \mathrm{g} / \mathrm{g}$ fresh tissue) of iron, zinc and copper in the duodenal mucosa of rats

(Mean values and their standard errors for seven rats per treatment)

\begin{tabular}{|c|c|c|c|c|c|c|}
\hline \multirow{2}{*}{$\begin{array}{c}\text { Length of } \\
\text { fast (h) }\end{array}$} & \multicolumn{2}{|c|}{$\mathrm{Fe}$} & \multicolumn{2}{|c|}{$\mathrm{Zn}$} & \multicolumn{2}{|c|}{$\mathrm{Cu}$} \\
\hline & Mean & $\mathbf{S E}$ & Mean & $\mathbf{S E}$ & Mean & $\mathbf{S E}$ \\
\hline 6 & 16 & 2 & 11 & 1 & 1.8 & 0.2 \\
\hline 16 & 22 & 4 & 16 & 2 & 2.6 & 0.4 \\
\hline 24 & 18 & 2 & 12 & 2 & 2.0 & 0.5 \\
\hline
\end{tabular}

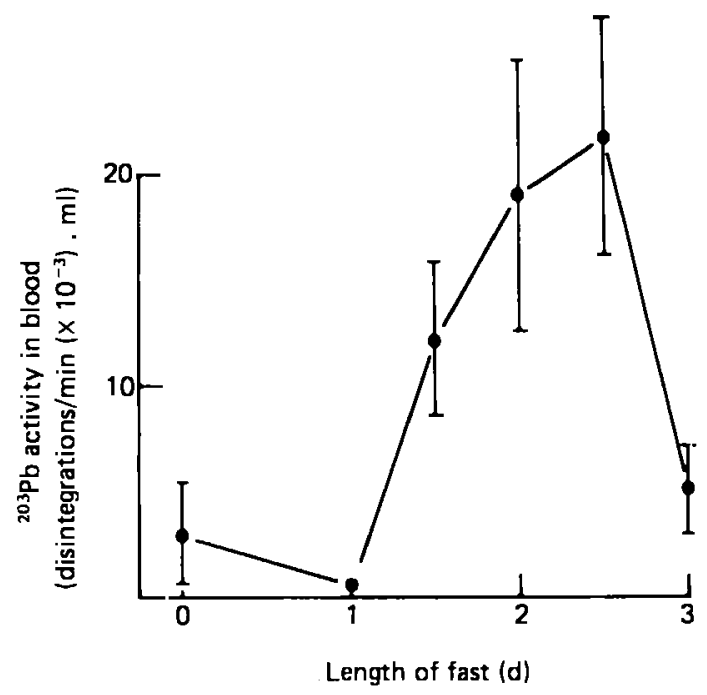

Fig. 3. The effect of fasting on the activity (disintegrations $/ \mathrm{min}\left(\times 10^{-3}\right) \mathrm{per} \mathrm{ml}$ ) of ${ }^{203} \mathrm{~Pb}$ in the blood of rats weighing approximalely $300 \mathrm{~g} 1 \mathrm{~h}$ after an oral dose of isotope. Points are mean values with their standard errors represented by vertical bars. 


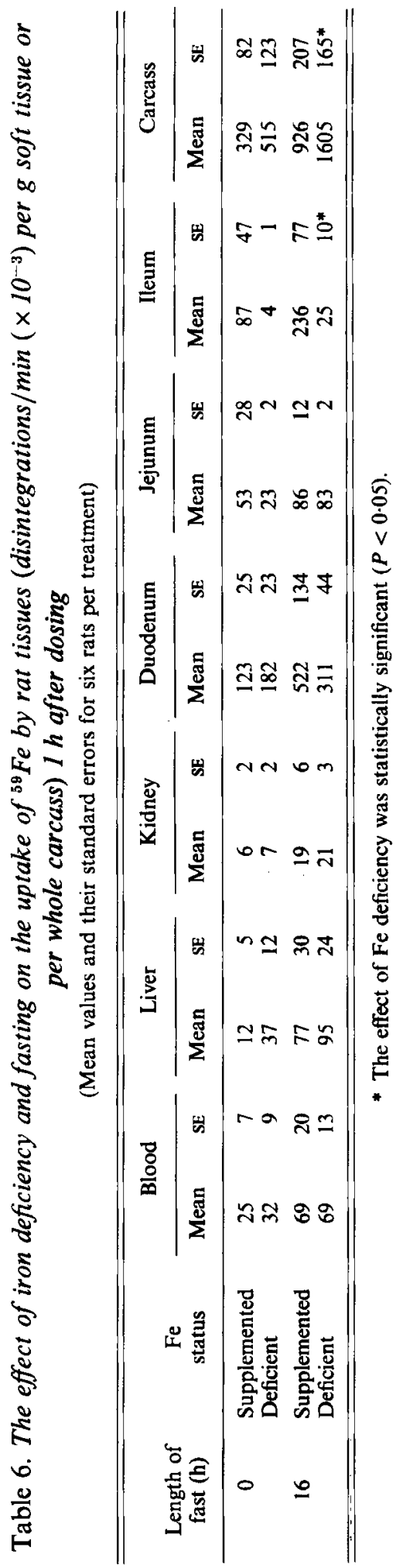


after $16 \mathrm{~h} 0.34 \pm 0.04 \mathrm{~g}$ and after $24 \mathrm{~h} 0.41 \pm 0.05 \mathrm{~g}$. The difference in weight of stomach contents between 6 and $16 \mathrm{~h}$ was significant $(P<0.05)$.

All the rats in the experiments previously described were about 100-125 $\mathrm{g}$ in weight, but in one experiment rats weighing approximately $300 \mathrm{~g}$ were used. In these rats with increasing lengths of fast there was an increase in ${ }^{203} \mathrm{~Pb}$ absorption followed by a decrease as with the younger rats but the tirne scale of the changes was different (Fig. 3). The rise in absorption did not start until afte: $1-1.5 \mathrm{~d}$ of fast and was maximum after $2.5 \mathrm{~d}$ fasting.

\section{DISCUSSION}

There is probably no experimental technique for investigating the effects of starvation on absorptive efficiency that is free from the possibility that the results may be influenced by the procedures adopted. Thus administration of isotopes directly into the stomach had the advantage that there is minimal interference with the normal functioning of the alimentary tract but the possible disadvantage that the results may be influenced by differences in the contents of the gut. The results presented in this paper show however that the presence of food in the gut at the time of dosing does not affect the absorption of the metal tracer because in spite of some differences in the mass of stomach contents the tissue retention after $6 \mathrm{~h}$ (Table 1, Fig. 1) and in some instances after 9 and $12 \mathrm{~h}$ (Table 2) of fasting was the same as that when the stomach was full of freshly-eaten food.

The thickness of the gut wall, the rate of absorption of nutrients, the extent of stomach fill and the rate of its emptying are influenced by the feeding-pattern of the animal (Fabry, 1962). In our experiments rats adapted to eating two meals/d did tend to absorb more of the oral dose of ${ }^{203} \mathrm{~Pb}$ than did rats eating continuously, but the effects of feeding-pattern were much smaller than those of a subsequent fast (Table 3).

The largest increases in absorption of the element occurred when fasting had continued for $16-24 \mathrm{~h}$. In one experiment with ${ }^{203} \mathrm{~Pb}$ in which an attempt was made to define more closely the length of fasting needed to produce this rise, it was found to occur between 12 and $16 \mathrm{~h}$, although in cther experiments the increase of absorption occurred only after fasts longer than $16 \mathrm{~h}$. The increase in absorption after 16-24 h occurred for all the metals examined, a major mineral, essential trace elements and toxic metals. Furthermore the increase varied with the length of fast both immediately after the dose in the absence of further food, as judged by the activity in the blood after $1 \mathrm{~h}$, and after $2 \mathrm{~d}$ during which the animals were fed normally.

The similarity in the pattern of increases of absorption of all the metals with increases in length of fast suggests that a common mechanism is involved. This includes $\mathrm{Ca}$ and $\mathrm{Fe}$ whose mechanisms of absorption have been intensively studied and involve different processes. Ca-binding protein (CaBP) concentration in the rat proximal small intestine has been reported to be decreased by $58 \%$ after a $22 \mathrm{~h}$ fast (Bruns et al. 1977) so the increased absorption which we have observed cannot be related to CaBP concentration. This observation supports the contention of Feher \& Wasserman (1979) that Ca absorption is not directly related to CaBP concentration in the intestinal mucosa.

The possibility that, at least in the instance of essential elements, the increased absorption after fasting is associated with changes in the concentration of the element in the mucosa or the lumen is excluded by several observations. The addition of stable carrier $\mathrm{Fe}$ to the dose of ${ }^{59} \mathrm{Fe}$ caused sorne decreases in the amount of ${ }^{59} \mathrm{Fe}$ absorbed but did not diminish the effect of fasting (Table 4), nor was the increase diminished by the previous consumption of a diet deficient in Fe (Table 6). Fasting did not change the mucosal concentration of $\mathrm{Fe}, \mathrm{Zn}$ or $\mathrm{Cu}$ (Table 5).

After $3 \mathrm{~d}$ of food deprivation the intestinal epithelium of the rat becomes smaller in weight with a decrease of total DNA, RNA and protein (Lichtenberger $e t$ al. 1976): these changes 
are measurable at 15-16 h starvation (McManus \& Isselbacher, 1970). In everted sacs from rats deprived of food for $3 \mathrm{~d}$ sodium and water transport are increased compared with sacs from fed rats (Beck \& Dinda, 1973). A possible explanation which could account for this was suggested by Steiner \& Gray (1969). They found that food deprivation had no effect on the absorption from a ligated loop of $2 \mathrm{~mm}$-valine but did increase absorption from a $10 \mathrm{~mm}$-solution. They suggested that mucosal cells formed after a period of fasting are more permeable than those formed in fed rats and when the lumen valine concentration was greater than physiological the effect of the increased diffusion became observable. The changes in lumen $\mathrm{pH}$ which occur after feeding may have an important but unknown role in metal absorption. These phenomena could account for the penetration of labelled tracers through the mucosa. There is also some histological evidence for a response of the absorptive capacity of the mucosa to starvation. As a result of starvation there is a shortening of the villi and a reduced rate of migration of newly-formed cells towards the tips (Brown et al. 1963; Rudo et al. 1976). A consequence of this is that there is an increased proportion of mature epithelial cells which have a greater absorptive capacity for nutrients (though not tested for heavy metals) than have younger cells. The idea that after a lag period of 12-24 h, during which there is a change in the nutritional status of the animal, mucosal cells are formed which have altered absorptive properties has also been put forward in regard to iron absorption. There is a lag of 8-24 h or more in the response of mucosal uptake to a changed Fe status (Linder et al. 1975).

The possibility that more permeable cells are formed after a period of food deprivation cannot however account for a number of the observations reported in this work. The uptake of ${ }^{203} \mathrm{~Pb}$ and ${ }^{59} \mathrm{Fe}$ by the mucosa, especially that of the duodenum, was increased by fasting (Tables 4 and 6, Fig. 2), so that its effects are at least in part intracellular. Whether or not this increase is related to the increased absorption of the metals may depend on whether the increase of metal transport occurs through the cells or between them, as is the instance with $\mathrm{Ca}$ secretion in the ileum (Nellans \& Kimberg, 1979). There was little increase in galactose transport after a $24 \mathrm{~h}$ fast, thus the increase in permeability similar to that of valine reported by Steiner \& Gray (1969) and of metals described here did not occur with this sugar. The small increase in galactose absorption which was observed after $24 \mathrm{~h}$ fasting may be related to the reduced weight of cells per unit length of intestine (Newry et al. 1970). A further objection to the suggestion of increased mucosal permeability with length of fasting is that in some experiments metal absorption decreased when the rats were deprived of food for longer than $24 \mathrm{~h}$ (Tables 1 and 2, Fig. 1).

No evidence is available about the effects of fasts longer than $40 \mathrm{~h}$ on heavy metal absorption except from such work as that of Richter (1974). He subjected rats to cycles of $3 \mathrm{~d}$ of starvation and $2 \mathrm{~d}$ of $\mathrm{ad} \mathrm{lib}$. feeding for 7 months with diets containing $0 \cdot 1$ to $12.3 \mathrm{~g}$ $\mathrm{Fe} / \mathrm{kg}$. The liver $\mathrm{Fe}$ contents $(\mu \mathrm{g} \mathrm{Fe} / \mathrm{g}$ liver per $\mathrm{g}$ Fe intake) of his starved-fed rats were approximately four times greater than the liver Fe contents of rats fed ad lib. with no starvation periods.

The effects of short fasts on metal absorption reported here are very large and must be taken into account in any studies of changes in absorptive efficiency. The periods of fasting imposed in our study were in many instances, similar to those arising in non-experimental conditions and which can occur regularly even on a daily basis and influence the retention of toxic metals contaminating the environment which find their way into the alimentary canal. This would not be the situation, however, with older rats where no change in absorption occurred during the first $24 \mathrm{~h}$ of starvation. At the moment there is no evidence on which to base any explanation for this age-related effect. The possibility that short fasts could affect metal uptake in humans during the daily feeding cycle is real however, since there is evidence that a fast of $6 \mathrm{~h}$ increased the uptake of ingested $\mathrm{Pb}$ (Rabinowitz et al. 1980). 


\section{REFERENCES}

Beck, I. T. \& Dinda, P. K. (1973). Can. J. Physiol. Pharmac. 51, 405.

Brown, H. O., Levine, M. L. \& Lipkin, M. (1963). Am. J. Physiol. $205,868$.

Bruns, M. E., Fleischer, E. B. \& Aviola, L. V. (1977). J. biol Chem. 252, 4145.

Ekenved: G. \& Arvidsson, B. (1976). Scand. J. Haematol. Supp. $28,79$.

Fabry, P. (1962). Feeding paitern and nutritional adaptations. London: Butterworths.

Feher, J. J. \& Wasserman, R. H. (1979). Am. J. Physiol. 236, E556.

Gruden, N. \& Buben, M. (1!79). Environ. Res. 18, 270.

Lichtenberger, L., Welsh, J. D. \& Johnson, L. R. (1976). Am. J. Dig. Dis. 21, 33.

Linder, M. C., Dunn, V., Jones, I. D., Lin, S., Van Volkom, M. \& Munro, H. N. (1975). Am. J. Physiol. 228, 196.

McManus, J. P. A. \& Isselbacher, K. J. (1970). Gastroenterol. 59, 214.

Mead, J. F., Bennett, L. R., Decker, A. B. \& Schoenberg, M. D. (1951). J. Nutr. 43, 477.

Nellans, H. N. \& Kimberg, D. V. (1979). Am. J. Physiol. 236, E473.

Newry, H., Sanford, P. A. \& Smyth, D. H. (1970). J. Physiol. 208, 705.

Ort, J. M. \& Benet, L. Z. (1975). Am. J. Dig. Dis. $20,858$.

Quarterman, J., Morrison, J. N. \& Humphries, W. R. (1976). Environ. Res. 12, 180.

Rabinowitz, M. B., Kopple, J. D. \& Wetherill, G. W. (1980). Am. J. clin. Nutr. 33, 1784.

Richter, G. W. (1974). Am. J. Path. 74, 481.

Rudo, N. D., Rosenberg, J. H. \& Wissler, R. W. (1976). Proc. Soc. exp. Biol. Med. 152, 277.

Steiner, M. \& Gray, S. J. (19.59). Am. J. Physiol. 217, 747.

Taylor, D. M., Bligh, P. H. \&: Duggan, M. H. (1962). Biochem. J. 83, 25.

Williams, R. B. \& Mills, C. F. (1970). Br. J. Nutr. 24, 989. 